\title{
Designing and Synthesis of New Fluorine Substituted Pyrimidine-Thion-5-Carbonitriles and the Related Derivatives as Photochemical Probe Agents for Inhibition of Vitiligo Disease
}

\author{
Mohammed S. T. Makki, Dina A. Bakhotmah", Reda M. Abdel-Rahman, Mohammed S. El-Shahawy \\ Department of Chemistry, Faculty of Science, King Abdulaziz University, Jeddah, Saudi Arabia \\ Email: *dbakhotmah@kau.edu.sa
}

Received August 20, 2012; revised October 11, 2012; accepted October 24, 2012

\begin{abstract}
A new biocidal agents fluorine substituted-3-thioxopyrimidine-5-carbonitriles (2-9) and/or the related fluorine substituted pyrimido $(\mathbf{4 , 5 - d})$ pyrimidines (10-14) were synthesized by the cycloaddition of fluorinated $\beta$-arylidine malononitriles (1a-c) followed by a nucleophilic attack against $\alpha, \beta$-bifunctional reagents in different conditions. Structures of the fluorine targets were characterized by their elemental analysis and spectral data (UV, IR, ${ }^{1} \mathrm{H} N M R,{ }^{13} \mathrm{C}$ NMR and mass measurements) and further evaluated as photochemical probe for inhibition of Vitiligo, it was found that compounds 5, 9, 11 and 12 exhibited high potency over the investigated compounds.
\end{abstract}

Keywords: Synthesis; Fluoropyrimidines; Photochemical Probes

\section{Introduction}

In the past few years fluorinated heterocyclic systems have been incorporated into drug discovery research [1-12] to improve the drug physicochemical properties and the antibacterial potency.

The DNA polymerase inhibitors Fludarabine (I) (Fara-A), Clofarabine (II) and Tezacitabine (III) are used as cancer chemotherapeutic agents [13] while Gleevec (IV) is used as a molecule catalytic inhibitor of imatinib messy- late [14]. In addition, BX-1382BS (V) showed a signifi- cant effect as a Protein Kinase inhibitor in cancer patients $[15,16]$ and that cyanopyrimidine scaffold JNJ17029259 (VI) is an oral inhibitor of VEGF-mediated signal transduction (Figure 1) [17].

The 4-amino-2-thioxopyrimidine-5-carbonitrile (2) and/ or 2,5,7-trithioxopyrimido[4,5-d]pyrimidine (3) were synthesized further reactions of $\mathbf{2}$ and $\mathbf{3}$ with $\alpha, \beta$-bifunctional reagents gave the fluorocompounds (4-13) (Schemes 1-3).

\section{Results and Discussion}

\subsection{Chemistry}

From cyclocondensation of fluorinated $\beta$-arylidene malononitrile (la-c) with thiourea in boiling ethanol [18] and in the presence of anhydrous $\mathrm{K}_{2} \mathrm{CO}_{3}$ (Scheme 1)

${ }^{*}$ Corresponding author.
4-Amino-6-fluoroaryl-1H-pyrimidine-5-carbonitriles (2ac) were obtained. UV spectrum structure of $2 \mathbf{a}$ showed $\lambda_{\max }$ at 370 and $314 \mathrm{~nm}$ assigned to higher heteroconjugation systems combined with $\pi-\pi^{*}$ electronic transition. Also, IR spectrum showed $v$ at 3358 and $2226 \mathrm{~cm}^{-1}$ assigned to the amino and cyano groups respectively. ${ }^{1} \mathrm{H}$ NMR spectrum of 2a showed resonated signals at $\delta 3.4$ and 8.7 ppm assigned to $\mathrm{NH}_{2}$ and $\mathrm{NH}$ protons. ${ }^{13} \mathrm{C}$ NMR spectrum of $\mathbf{2 a}$ showed signals at $\delta 166,114$ and $180 \mathrm{ppm}$ assigned to the $\mathrm{C}-\mathrm{CN}, \mathrm{C} \equiv \mathrm{N}$ and $\mathrm{C}=\mathrm{S}$ carbons with $165,130,115$ ppm of C-F aromatic carbons. It was interesting to note that refluxing compound $\mathbf{2}$ with carbon disulfide in DMF [18] afforded4-fluoroaryl-2,5,7-trithioxo-1,6,8-trihydropyrimido[4,5-d]pyrimidine (3) (Scheme 1).

The electronic conjugated molecules of compound $\mathbf{3}$ exhibited $\lambda_{\max }$ at $317 \mathrm{~nm}$. Due to the $3 \mathrm{NH}$, IR spectrum showed vibration bands at $v 3305,3170$ and $3095 \mathrm{~cm}^{-1}$ with 1298 and $1222 \mathrm{~cm}^{-1}$ which were attributed to cyclic NCS and C-S groups. ${ }^{1} \mathrm{H}$ NMR spectrum showed resonated signals at $\delta 8.5,12.01$ and $13.2 \mathrm{ppm}$ for $3 \mathrm{NH}$ different types of carbons were recorded by ${ }^{13} \mathrm{C}$ NMR spectrum at $\delta 83$ (N-C-N), 136, 116 (C-Ar) and also at $\delta 178,180 \mathrm{ppm}$ and $194 \mathrm{ppm}$ assigned to $3 \mathrm{C}=\mathrm{S}$ with $\delta$ at 165,128 and 118 ppm of aryl carbon-fluorine. The base peak for compound 3 was recorded at m/z 95 as 4-fluorophenyl cation (Scheme 5).

4-Thiazolidinones possess biological and pharmacol- 
<smiles>[R][R]P([R])(=O)OC[C@H]1O[C@@](C)(n2cnc3c(N)nc(F)nc32)[C@H](O)[C@@H]1O</smiles>

Figure 1. Chemotherapeutic fluorinated pyrimidines.

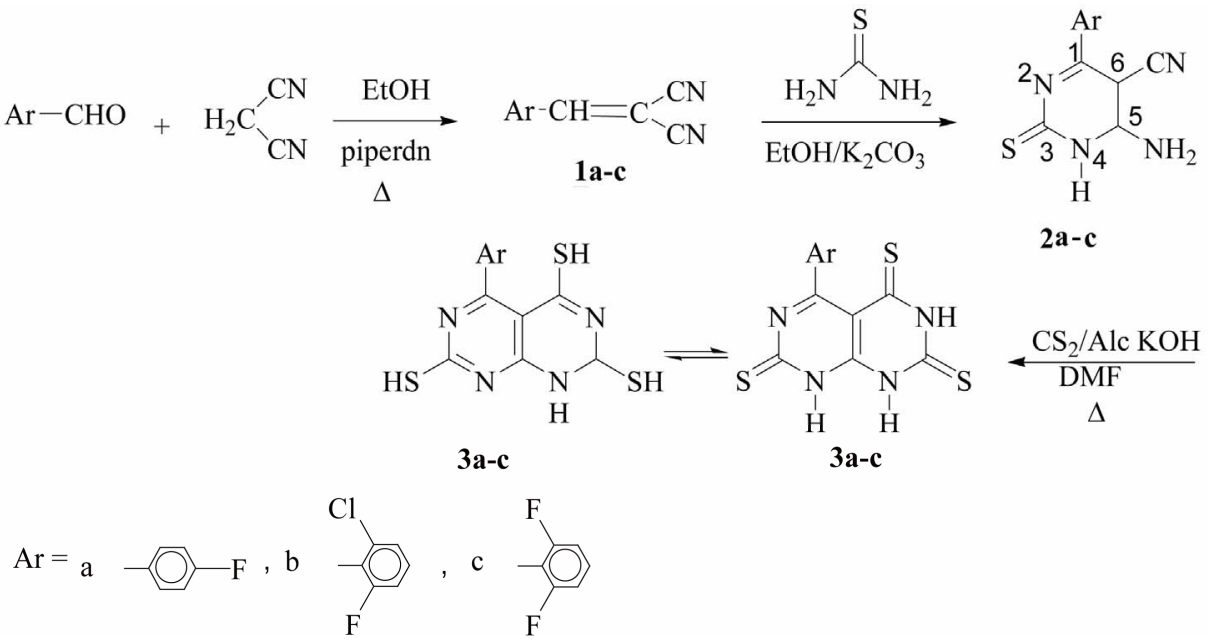

Scheme 1. $\beta$-arylidene malononitrile (la-c).

ogical activities as plant protecting, anticancer and anti AIDS agents [19]. Based on these activities, condensation of compound 2a with 4-fluorobenzaldehyde in ethanol yielded the Schiff base 4, which upon cycloaddition reacted with mercaptoacetic acid to give 4-[2'-(4"-fluorophenyl-4'-oxothiazolidin-3'-yl)]-6-(4-fluorophenyl)-1H-pyrimidine-5-acetonitrile (5) (Scheme 2).

The $\mathrm{OH}$ and $\mathrm{NH}$ absorption bands of structure 5 which was deduced from both elemental analysis and spectral measurements of IR spectrum were shown at at 3373 and $3329 \mathrm{~cm}^{-1}$ respectively, with $2229,1647(\mathrm{C} \equiv \mathrm{N} \& \mathrm{C}=\mathrm{O})$ and at $1222 \mathrm{~cm}^{-1}(\mathrm{C}-\mathrm{S}) .{ }^{1} \mathrm{H}$ NMR spectrum recorded resonated signals at $\delta 4.7(\mathrm{CH}=$ of thiazolidinone) $9.7(\mathrm{NH}$ of pyrimidine) and at 10.2 (3-OH of thiazole) with aromatic protons at $\delta 7.9-7.1 \mathrm{ppm}$. Resonated signals were recorded by ${ }^{13} \mathrm{C}$ NMR spectrum at $\delta 180,163,162$ due to the presence of $\mathrm{C}=\mathrm{S}, \mathrm{C}=\mathrm{O}$, and $\mathrm{C}-\mathrm{F}$ and 114.3, 130.1, $163.89 \mathrm{ppm}$ of imidazole moiety. The signals which were observed at $\delta 115.5,114.88,128,130 \mathrm{ppm}$ also, were assigned to $\mathrm{C}=\mathrm{N}$ and aromatic carbons respectively.

Condensation of 4-amino-6-(4'-fluorophenyl)-1-H-py- rimidine-5-carbonitrile (2a) with oxazol-5-one derivative 6 in boiling dry pyridine produced 4[4'-(4"-fluorobenzylidene)-2-phenyl-5-oxo-imidazol-1'-yl]-6-(4'-fluoro-phenyl)-IH-pyrimidine-5-carbonitrile (7) (Scheme 2). UV absorption of 7 recorded $\lambda_{\max }$ at $360 \mathrm{~nm}$ assigned to $\mathrm{n}-\pi^{*}$ electronic transition with a conjugated system of imidazolone. Absorption bands at $v 3329,2225$ and $1650 \mathrm{~cm}^{-1}$ attributed to $\mathrm{NH}, \mathrm{C} \equiv \mathrm{N}$ and $\mathrm{C}=\mathrm{O}$ functional groups, in addition at 1248, and $1130 \mathrm{~cm}^{-1}$ assigned to NCS and C-S with $677 \mathrm{~cm}^{-1}$ characterized by C-F group were shown by the IR spectrum. ${ }^{1} \mathrm{H}$ NMR spectrum exhibited a resonated signal at $\delta 13.3$ and with $8.6 \mathrm{ppm}$ due to $\mathrm{NH}$ and exo $\mathrm{CH}$ protons of imidazolone, with aromatic protons between 7.8 $6.8 \mathrm{ppm}$. Similarly, cyclocondensation of 2,3-pyridinedicarboxylic acid anhydride (8) with compound 2a in boiling dry pyridine, afforded 4-(2',3'-phthalimidopyridin-l'-yl)-6(4'-fluorophenyl)-1-H-pyrimidine-5-carbonitrile (9) (Scheme 2).

Due to $n-\pi^{*}$ electronic system UV absorption spectrum of 9 exhibited $\lambda_{\max }$ at $302 \mathrm{~nm}$. Peaks were recorded by IR spectrum at $v 3334,2216$ and $1689 \mathrm{~cm}^{-1}$ which were 


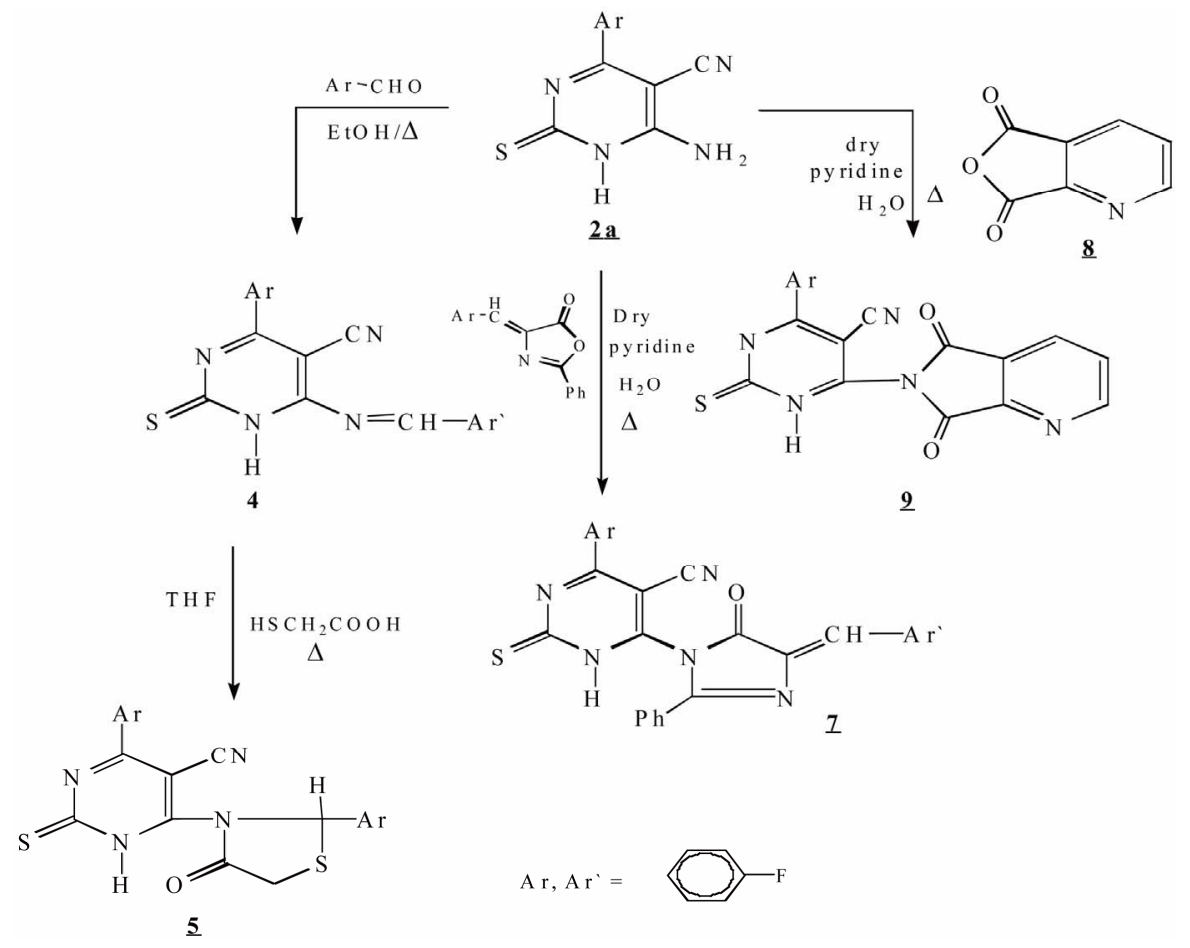

Scheme 2. Condensation of compound 2a.

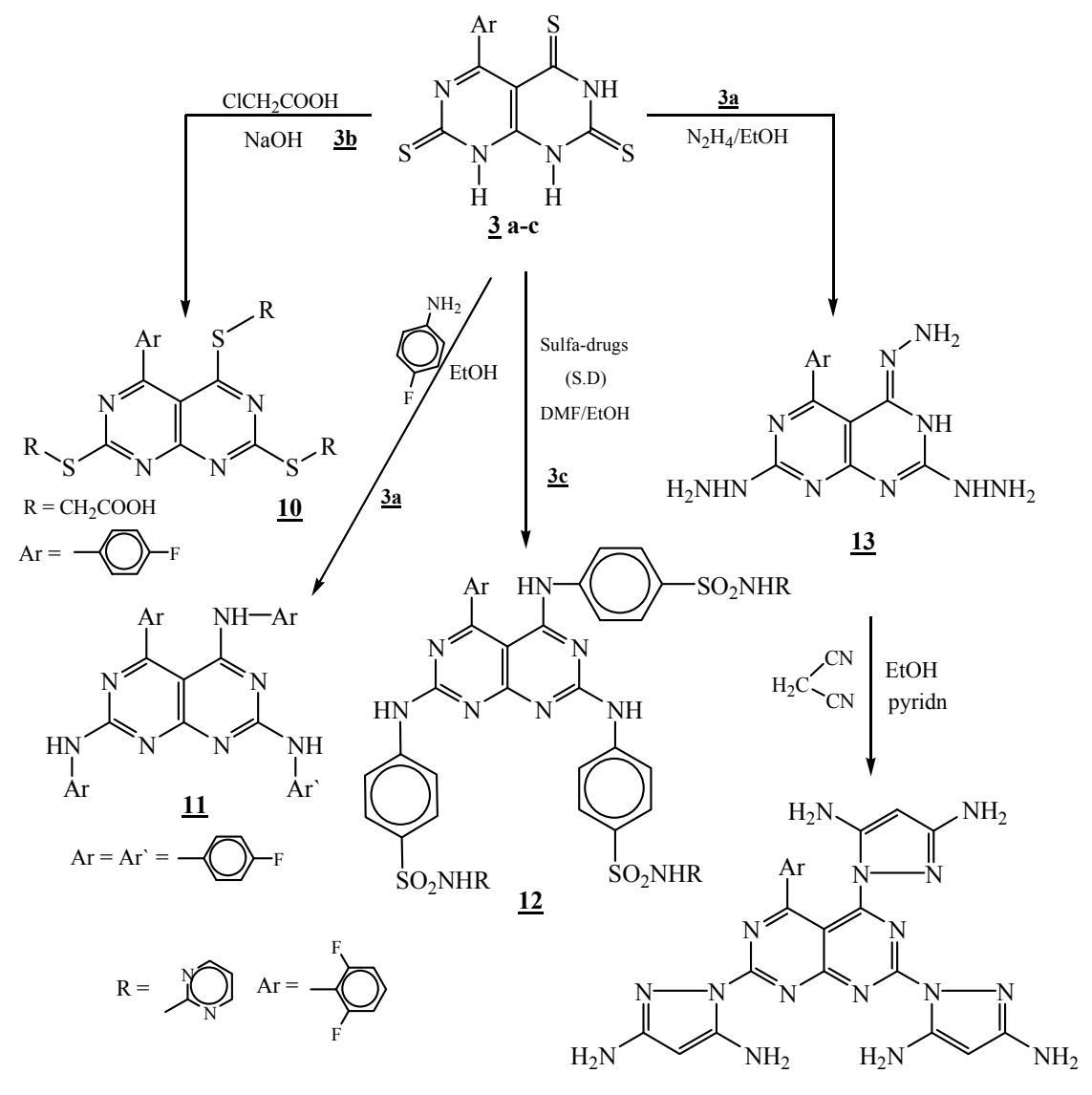

$\underline{14}$

Scheme 3. Synthesis of fluoro compounds 10-14. 

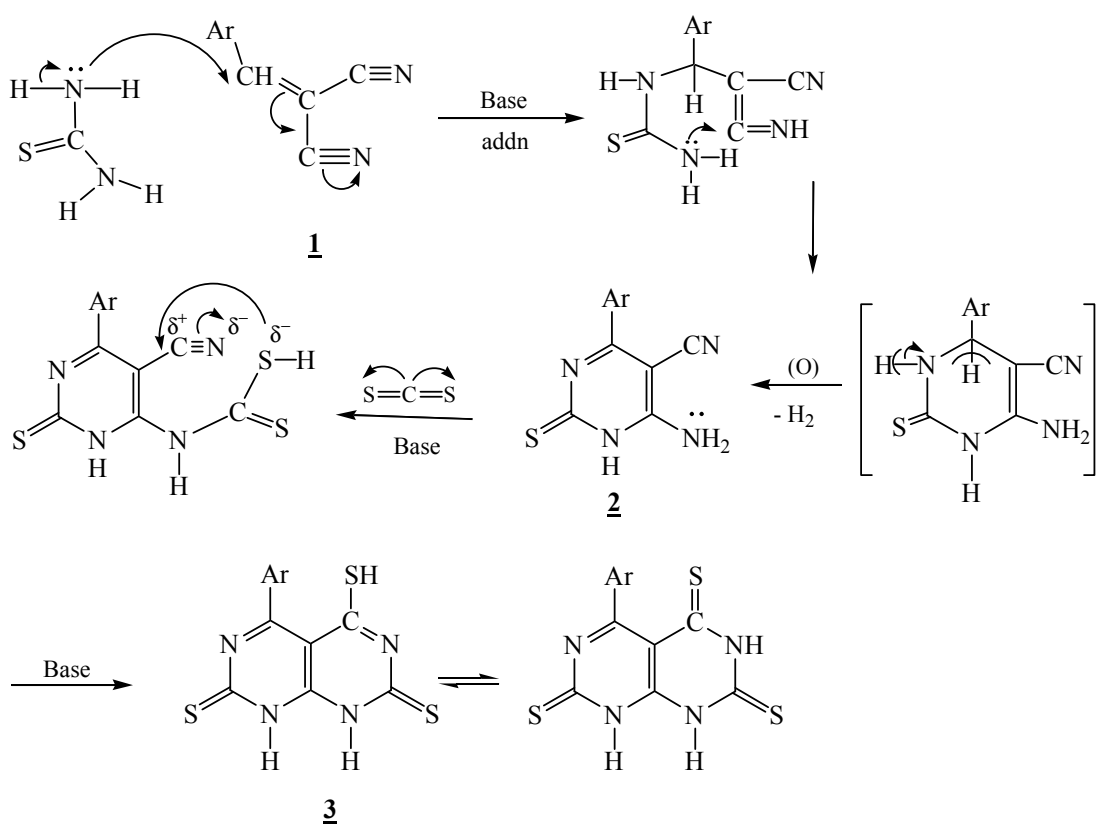

Scheme 4. The formation of fluoropyrimidine 3.<smiles>Fc1ccc(-c2nc(=S)[nH]c3[nH]c(=S)[nH]c(=S)c23)cc1</smiles>

3a $325(5 \%)$ $\left(\mathrm{M}^{+}+3\right)$<smiles>Fc1ccccc1</smiles>

$95(100 \%)$ Base peak<smiles>Cc1c(-c2ccc(F)cc2)nc(=S)[nH]c1NC(=S)NC(C)C</smiles>

$278(12 \%)$

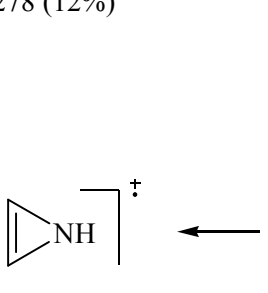

41

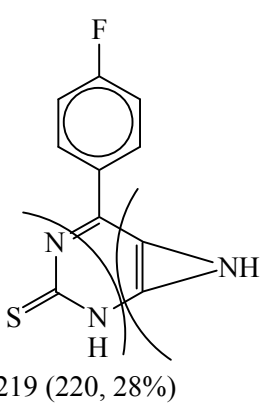

Scheme 5. Mass fragmentation pattern of compound 3a.

assigned to $\mathrm{NH}, \mathrm{C} \equiv \mathrm{N}$ and $\mathrm{C}=\mathrm{O}$ functional groups. In addition, peaks at 810,770 and $750 \mathrm{~cm}^{-1}$ were assigned to aromatic ring. ${ }^{1} \mathrm{H}$ NMR showed a resonated signal at $\delta$ $10.1 \mathrm{ppm}$ assigned to $3 \mathrm{NH}$ with aromatic protons at $8.1-$ $6.8 \mathrm{ppm}$.

An amylolytic activity against some fungi [20] was shown by $1,2,4$-Triazines bearing carboxymethylthia groups. Accordingly, alkylation of $\mathbf{3}$ using chloroacetic acid in aqueous $\mathrm{NaOH}$ yielded 8-aryl-2,5,7-tri(carboxymethylthia) pyrimido[4,5-d]pyrimidine (10) (Scheme 3). Formation of $\mathbf{3}$ is shown in (Scheme 4). Structure of $\mathbf{1 0}$ was derived from its elemental analysis and spectral data. UV absorption spectrum was recorded $\lambda_{\max }$ at $269 \mathrm{~nm}$, while IR spectrum showed absorption bands at 3400,1700 and $1480 \mathrm{~cm}^{-1}$ which were attributed to $\mathrm{OH}$, $\mathrm{C}=\mathrm{O}$ and $\mathrm{CH}_{2}$ groups in addition $v 1180$ and $690 \mathrm{~cm}^{-1}$ were assigned to $\mathrm{C}-\mathrm{S}$ and $\mathrm{C}-\mathrm{F}$ groups. Due to the presence of $3(\mathrm{COOH})$ protons and aromatic protons ${ }^{1} \mathrm{H}$ NMR spectrum recorded signals at $\delta 9-7.2(\mathrm{~m}) \mathrm{ppm}$ in addition, at $3.3-3.6 \mathrm{ppm}$ for active methylene protons. ${ }^{13} \mathrm{C}$ NMR spectrum showed a resonated signal at $\delta 171.15$, $171,163.85$ ppm which were assigned to $\mathrm{C}-\mathrm{S}, \mathrm{C}=\mathrm{O}, \mathrm{C}-\mathrm{F}$ 
and at 162.5, 162.11, 154.15, $114 \mathrm{ppm}$ attributed to $2 \mathrm{C}=\mathrm{N}$ of substituted pyrimidine, $\mathrm{C}=\mathrm{C}$ of condensed pyrimidine. In addition, at $33.88 \mathrm{ppm}$ of $\mathrm{C}\left(\mathrm{S}-\mathrm{CH}_{2}-\mathrm{CO}\right)$ with $130.15,115.35$ of aromatic carbons.

In the treatment of HIV and cancer diseases fluorinated heterocyclic nitrogen systems possess specific and unique properties as drugs [21-23]. Based on these observations, a simple nucleophilic attack for removal of sulfur atoms of compound 3a yielded 4-aryl-2,5,7-tri(4'fluorophenylamino)-pyrimido[4,5-d]-pyrimidine (11) (Scheme 3). Also, treatment of 3a with sulfa-drug as sulfadiazine in boiling DMF yielded 4-aryl-2,5,7-tri(4'-sulfonamoylphenylamino)-pyrimido[4,5-d]-pyrimidine (12) (Scheme 3).

UV absorption of 11 showed band at $\lambda_{\max }$ at $271 \mathrm{~nm}$, IR bands at $v 3197,1575,1219$ and $776 \mathrm{~cm}^{-1}$ assigned to $\mathrm{NH}, \mathrm{C}=\mathrm{N}, \mathrm{NCS}$ and $\mathrm{C}-\mathrm{F}$ functional groups. Resonated signals were shown by ${ }^{1} \mathrm{H}$ NMR spectrum at $\delta 10.1$ and in the range $\delta 7.2-7.9 \mathrm{ppm}$ of $3 \mathrm{NH}$ of pyrimidines with aromatic protons respectively.

Hydrazino groups are used as starting materials for bioactive isolated heterobicyclic systems [24-26]. Refluxing 3a with hydrazine hydrate in ethanol produced 4-aryl-2,5,7-tri(hydrazinopyrimido[4,5-d]pyrimidine (13) Ring closure reactions of $\mathbf{1 3}$ with malononitrile in boiling ethanol with a few drops of piperidine as a catalyst via cycloaddition led to the direct formation of 8-(4'-fluorophenyl)-2,5,7-tri(3',5'-diaminopyrazol-1'-yl) pyrimido [4,5-d]pyrimidine 14 (Scheme 3).

Structure of 14 was deduced from elemental analysis and spectral data. UV absorption was recorded $\lambda_{\max }$ at 350 and 310 run assigned to a rich $n-\pi^{*}$ and $n-\sigma^{*}$ electronic transition. IR spectrum showed bands at $v 3240$, $1664 \mathrm{~cm}^{-1}$ due to $\mathrm{NH}_{2}$ group with other peaks at 1609 , $1574 \mathrm{~cm}^{-1}$ for $\mathrm{C}=\mathrm{N}$ with $776 \mathrm{~cm}^{-1}$ of $\mathrm{C}-\mathrm{F}$ functional groups. ${ }^{1} \mathrm{H}$ NMR spectrum showed a signal at 3.3 - 3.6 ppm attributed to $6 \mathrm{NH}_{2}$ protons, with aromatic protons at $\delta 7.2$ and $8.18-8.0$ ppm of three $\mathrm{CH}$ of 4-pyrazoles. ${ }^{13} \mathrm{C}$ NMR showed signals at $\delta 162.45,162.13 \mathrm{ppm}$ of C-F and two $\mathrm{C}=\mathrm{N}$ of substituted pyridine in addition at $\delta$ $152.55,148.85 \mathrm{ppm}$ attributed to $2 \mathrm{C}_{2}-\mathrm{NH}_{2}$ of pyrazole with chemical shifts at 155.9 and 77.85 of $\mathrm{C}_{4}=\mathrm{C}_{5}$ of fused pyrimidopyrimidine. Other signals of pyrazole were observed at $\delta 162.45,77.85$ of $\mathrm{C}-\mathrm{F}$ and $\mathrm{C}=\mathrm{C}$ besides aromatic carbons at $\delta 130,127,115.88 \mathrm{ppm}$ which confirmed the proposed structure. The molecular ion was recorded by the mass spectrum at $\mathrm{m} / \mathrm{z} 514$ (5\%) with a base peak at m/z $132(100 \%)$ attributed to a delocalized pyrimidopyrimidine radical. Synthesized single fluorine which was attached to phenyl ring in all the fluorinated systems appeared in the region at $\delta-120-126 \mathrm{ppm}$.

\subsection{Pharmacology}

Vitiligo is an acquired disorder which is characterized by patchy progressive depigmentation of the skin. About $2 \%$ of the world population is affected by it. Thus, by using the disk diffusion method the antimicrobial activity of the prepared fluorinated pyrimidine compounds was performed [27,28] at concentrations of 100, 75 and 50 $\mu \mathrm{g} /$ disk with the interference drugs, Chloroamphenicol (10 $\mu \mathrm{g} /$ disk) and Nalidixic acid $(20 \mu \mathrm{g} / \mathrm{disk})$ for bacteria and Nystatin (30 unit/disk $=0.12 \mu \mathrm{g} / \mathrm{disk}$ ) for fungi. The disks were placed on the surface of the cold medium and incubated with Bacillus subtilis and Staphylloccocus aureus (Gram + ve bacteria) Esherichia coli and Pseudomonas aeruginosa (Gram - ve bacteria) and Candida albicans (fungi) at $25^{\circ} \mathrm{C}$ for one hour to permit good diffusion and were then transferred to an incubator at $37^{\circ} \mathrm{C}$ for 24 hours. The results are summarized in (Table 1). Before transferring it to the incubator the photochemical screening employing UV light at $366 \mathrm{~nm}$ was also carried out following the same procedure without UV for 3 hours. The results are given in (Table 2). The sensitivity of fluorinated compounds against microorganisms revealed the following observations:

1) High MIC for the tested compounds against positive bacteria was achieved at $50 \mu \mathrm{g} /$ disk concentration, while that of negative bacteria at $100 \mu \mathrm{g} / \mathrm{disk}$ and for fungi at $50 \mu \mathrm{g} / \mathrm{disk}$.

2) After using UV light at $50 \mu \mathrm{g} / \mathrm{mL}^{-1}$ all the targets exhibited high effects.

3) Most of the tested compounds were highly active (Iz $12-15$ ) at $50-100 \mu \mathrm{g} / \mathrm{mL}^{-1}$ and others showed a moderate activity (Iz $9-12$ ) at the same concentration in comparison to the standard antibiotics.

4) The presence of the fluorine atoms enhanced the activity until the concentration is $50 \mu \mathrm{g} / \mathrm{disk}$.

5) Increasing fluorine atoms led to increasing of biocidal effects. Also, introducing sulfa moieties increased the biocidal effects.

6) The compounds which combined heterocyclic systems with both the fluorine and sulfa drugs moiety exhibited higher biocidal effects before and after using UV light especially with compounds 5, 9, 11 and 12 which can be used in antimicrobial and photochemical probe agents especially towards +ve bacteria.

Through Quantitative-structure activity relationship (QSAR) for the tested compounds it was showed that the cytotoxicity of these compounds is controlled by electronic and hydrophobic factors as well as by steric factor which is due to the large size of molecular formula and the electronegativities $(\mathbf{5}, \mathbf{9}, \mathbf{1 1}, \mathbf{1 2})$. Thus, the electron density on the active center of the tested target increased the biocidal effect.

In comparison with the standard antibiotics e.g. chloroamphenicol, Nalidixic acid and Nystatin compounds 11 and 12 can be used as antimicrobial and anti- 
Table 1. Preliminary screening antimicrobial activity of the fluorinated compounds 2-12.

\begin{tabular}{|c|c|c|c|c|c|c|c|c|c|c|c|c|c|c|c|c|c|c|c|c|c|c|c|c|c|}
\hline \multirow{4}{*}{$\begin{array}{c}\text { Compd } \\
\text { NO. } \\
\text { Conc. }\end{array}$} & \multicolumn{25}{|c|}{ Microorganisms Inhibition Zones (mm) } \\
\hline & \multicolumn{10}{|c|}{ (+ve bacteria) } & \multicolumn{10}{|c|}{ (-ve bacteria) } & \multirow{2}{*}{\multicolumn{5}{|c|}{$\begin{array}{c}\text { (Fungi) } \\
\text { Candida albicans }\end{array}$}} \\
\hline & \multicolumn{5}{|c|}{ Bacillus s. } & \multicolumn{5}{|c|}{ Staphylloccocus a. } & \multicolumn{5}{|c|}{ Escherichia coli } & \multicolumn{5}{|c|}{ Pseudomonas aeruginase } & & & & & \\
\hline & 100 & 75 & 50 & 25 & 10 & 100 & 75 & 50 & 25 & 10 & 100 & 75 & 50 & 25 & 10 & 100 & 75 & 50 & 25 & 10 & 100 & 75 & $\mathbf{5 0}$ & 25 & 10 \\
\hline 2 & 15 & 15 & 9 & - & - & 15 & 12 & 8 & - & - & 15 & 12 & - & - & - & 13 & - & - & - & - & 9 & - & - & - & - \\
\hline 3 & 15 & 15 & 9 & - & - & 15 & 13 & 8 & - & - & 12 & - & - & - & - & 13 & - & - & - & - & 9 & - & - & - & - \\
\hline 5 & 15 & 15 & 9 & - & - & 15 & 13 & 8 & - & - & 12 & - & - & - & - & 12 & - & - & - & - & 9 & - & - & - & - \\
\hline 7 & 15 & 15 & 9 & - & - & 15 & 13 & 8 & - & - & 12 & - & - & - & - & 13 & - & - & - & - & 9 & - & - & - & - \\
\hline 9 & 15 & 15 & 9 & - & - & 15 & 13 & 8 & - & - & 13 & 9 & - & - & - & 12 & - & - & - & - & 9 & - & - & - & - \\
\hline 11 & 15 & 15 & 11 & - & - & 15 & 13 & 9 & - & - & 13 & 12 & - & - & - & 13 & - & - & - & - & 11 & - & - & - & - \\
\hline 12 & 15 & 15 & 13 & - & - & 15 & 13 & 12 & - & - & 15 & 13 & - & - & - & 15 & - & - & - & - & 13 & - & - & - & - \\
\hline
\end{tabular}

Chloroamphenical: for Bacteria; $\mathrm{IZ}=15$; Nalidixic: Non-Selective for Bacteria; Nystatin for Fungi.

Table 2. Preliminary screening antimicrobial activity of the fluorinated compounds 2-12 after using UV-light (366 nm).

\begin{tabular}{|c|c|c|c|c|c|c|c|c|c|c|c|c|c|c|c|c|c|c|c|c|c|c|c|c|c|}
\hline \multirow{4}{*}{$\begin{array}{c}\text { Compd } \\
\text { NO. } \\
\text { Conc. }\end{array}$} & \multicolumn{25}{|c|}{ Microorganisms Inhibition Zones (mm) } \\
\hline & \multicolumn{10}{|c|}{ (+ve bacteria) } & \multicolumn{10}{|c|}{ (-ve bacteria) } & \multirow{2}{*}{\multicolumn{5}{|c|}{$\begin{array}{c}\text { (Fungi) } \\
\text { Candida albicans }\end{array}$}} \\
\hline & \multicolumn{5}{|c|}{ Bacillus s. } & \multicolumn{5}{|c|}{ Staphylloccocus a. } & \multicolumn{5}{|c|}{ Escherichia coli } & \multicolumn{5}{|c|}{ Pseudomonas aeruginase } & & & & & \\
\hline & 100 & 75 & 50 & 25 & 10 & 100 & 75 & 50 & 25 & 10 & 100 & 75 & 50 & 25 & 10 & 100 & 75 & 50 & 25 & 10 & 100 & 75 & 50 & 25 & 10 \\
\hline 2 & 15 & 15 & 11 & - & - & 15 & 12 & 12 & - & - & 15 & 13 & - & - & - & 13 & - & - & - & - & 9 & - & - & - & - \\
\hline 3 & 15 & 15 & 11 & - & - & 15 & 14 & 12 & - & - & 12 & - & - & - & - & 13 & - & - & - & - & 9 & - & - & - & - \\
\hline 5 & 15 & 15 & 11 & - & - & 15 & 15 & 12 & - & - & 12 & - & - & - & - & 13 & - & - & - & - & 9 & - & - & - & - \\
\hline 7 & 15 & 15 & 11 & - & - & 15 & 15 & 12 & - & - & 12 & - & - & - & - & 13 & - & - & - & - & 9 & - & - & - & - \\
\hline 9 & 15 & 15 & 11 & - & - & 15 & 15 & 12 & - & - & 15 & 9 & - & - & - & 13 & - & - & - & - & 9 & - & - & - & - \\
\hline 11 & 15 & 15 & 11 & - & - & 15 & 15 & 13 & - & - & 15 & 13 & - & - & - & 13 & - & - & - & - & 11 & - & - & - & - \\
\hline 12 & 15 & 15 & 15 & - & - & 15 & 15 & 15 & - & - & 15 & 15 & - & - & - & 15 & - & - & - & - & 13 & - & - & - & - \\
\hline
\end{tabular}

fungal agents in the treatment of Vitiligo [26,27].

The prominent role of fluorine substituent effects on bioactivity is due to the effect of fluorination on $\mathrm{C}-\mathrm{H}$ acidity which normally is predictable and depends on several factors, including the site of fluorination and geometry of the conjugate carbanion. Thus, $\alpha$-fluorine can increase or decrease acidity. The latter is the case when the conjugate carbanion is close to planar since this geometry maximizes lone-pair repulsions. $\beta$-Fluorine invariably increases $\mathrm{C}-\mathrm{H}$ acidity through inductive and hyper conjugative resonance stabilization of the carbanion (Figure 2) [8].

\section{Conclusion}

Fluorinated pyrimidines and pyrimido[4,5-d] pyrimidine derivatives 2-14 were efficiently synthesized beginning from fluorinated $\beta$-arylidine malononitriles 1. A significant activity was shown by all of these targets against Basillus subtilis, and Staphylloccous aureus (Gram + ve bacteria) Esherichia coli and Pseudomonas aeruginase (Gram - ve bacteria) and Candida albicans as fungi. In general the presence of fluorine atom increased the antimicrobial activity at $50 \mathrm{mg} / \mathrm{disk}$ and especially increased the biocidal effects towards +ve bacteria. After using UV-light, the biocidal effects of the tested compounds also increased towards +ve bacteria, especially the compounds 5, 9, 11 and 12. On the other hand, the high effects of these compounds may be attributed to the three signal excitation states of oxygen atom. Thus, for inhibition of Vitiligo disease the fluorinated pyrimidine derivatives can be used as photochemical probe agents.

\section{Experimental Section}

\subsection{General Procedures}

Melting points were determined with an electrothermal Bibby Stuart Scientific melting point Smpl (US). A Perkins Elmer model RXI-FT-IR system 55529 was used for 


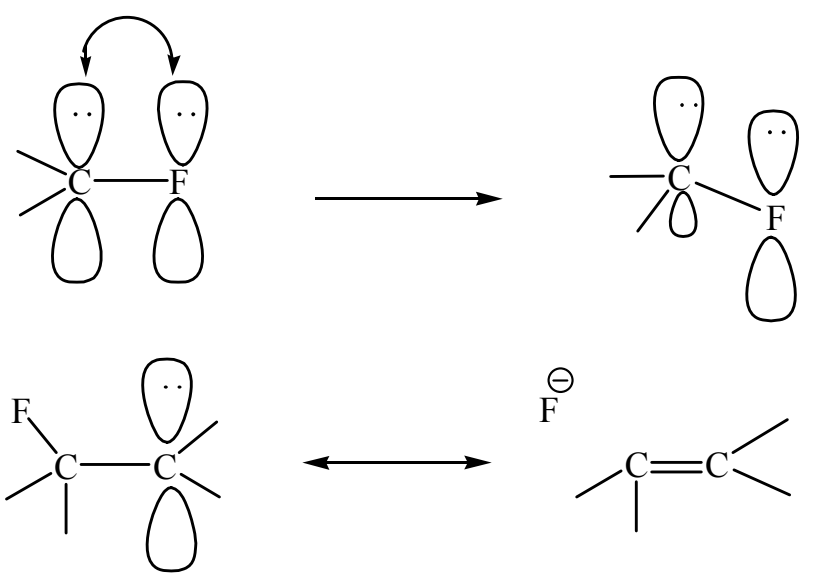

Figure 2. Hyper-conjugation between F-atoms and C-H.

recording the IR spectra of the prepared compounds. A Brucker advance DPX $400 \mathrm{MHz}$ model using TMS as an internal standard was used for recording the ${ }^{1} \mathrm{H}$ and ${ }^{13} \mathrm{C}$ NMR spectra of the compounds on deuterated DMSO. A GC-MS-QP 1000-Ex model was used for recording the mass spectra of the compounds. Electronic spectra were recorded in ethanol on Shimadzu UV and visible 3101 PC Spectrophotometer. Microanalysis (Molecular weight determination) was performed by the Microanalytical Center of Cairo University, Egypt. M/S spectroscopy was determined on a GCMS-Q 1000-Ex spectrometer at 75 $\mathrm{eV}$ in $\mathrm{m} / \mathrm{z}$. Hexafluorobenzene was used as external standard for ${ }^{19} \mathrm{~F} \mathrm{NMR}$ at $8425 \mathrm{MHz}$ (Chemical shift in $\delta$, ppm).

\subsubsection{Fluorinated $\beta$-Arylidene Malononitriles (1a-c) [18]}

la: Crystallized from dioxan as faint yellow crystals. Yield $=85 \%$, m.p. $85^{\circ} \mathrm{C}-87^{\circ} \mathrm{C}$. Analytical data: Found: $\mathrm{C}$ $=69.36, \mathrm{H}=2.8, \mathrm{~N}=16.01$, and $\mathrm{F}=10.72 \%$. Calculated for $\mathrm{C}_{10} \mathrm{H}_{5} \mathrm{~N}_{2} \mathrm{~F}$ (172): $\mathrm{C}=69.76, \mathrm{H}=2.90, \mathrm{~N}=16.27$ and $\mathrm{F}=11.04 \%$. IR (KBr disk) $v \mathrm{~cm}^{-1}: 3049$ (C-H arom.), 2929 (C-H aliphatic), $2230(\mathrm{C} \equiv \mathrm{N}), 1610(\mathrm{C}=\mathrm{C}), 1210$ (C-F), 820 (substituted phenyl). UV (EtOH) $\lambda_{\max }(\mathrm{nm})$ $279(\log \epsilon=2.5) .{ }^{1} \mathrm{H}$ NMR (DMSO) $\delta: 5.5(1 \mathrm{H}, \mathrm{CH}=)$, 7.5 - $7.6(\mathrm{~d}, 2 \mathrm{H}$, aromatic protons), 7.7 - $7.8(\mathrm{~d}, 2 \mathrm{H}$, aromatic protons).

lb: Crystallized from dioxan to give pale yellow crystals. Yield $=62 \%$, m.p. $65^{\circ} \mathrm{C}-67^{\circ} \mathrm{C}$. Analytical data: Found: $\mathrm{C}=58.01, \mathrm{H}=1.91, \mathrm{~N}=13.44, \mathrm{Cl}=16.81$ and $\mathrm{F}$ $=8.88 \%$. Calculated for $\mathrm{C}_{10} \mathrm{H}_{4} \mathrm{~N}_{2} \mathrm{ClF}$ (206.5): $\mathrm{C}=58.25$, $\mathrm{H}=1.94, \mathrm{~N}=13.59, \mathrm{Cl}=16.99$ and $\mathrm{F}=9.2 \%$.

lc: Crystallized from dioxan to give pale yellow crystals. Yield $=90 \%$, m.p. $119^{\circ} \mathrm{C}-120^{\circ} \mathrm{C}$. Analytical data: Found: $\mathrm{C}=62.95, \mathrm{H}=1.99, \mathrm{~N}=14.64$, and $\mathrm{F}=19.88 \%$. Calculated for $\mathrm{C}_{10} \mathrm{H}_{4} \mathrm{~N}_{2} \mathrm{~F}_{2}$ (190): $\mathrm{C}=63, \mathrm{H}=2.10, \mathrm{~N}=$ 14.73 and $\mathrm{F}=20.0 \%$.

\subsubsection{4-Amino-6-fluoroaryl-2-thioxo-1H-pyrimidine- 5-carbonitriles (2a-c)}

A mixture of compound 1a-c $(0.01 \mathrm{~mol})$, thiourea $(0.01$ $\mathrm{mol})$, anhydrous $\mathrm{K}_{2} \mathrm{CO}_{3}(0.01 \mathrm{~mol})$, in ethanol $(30 \mathrm{ml})$ was refluxed for $3 \mathrm{~h}$. The precipitate obtained was washed with water and crystallized to give $\mathbf{2 a - c}$.

2a: Crystallized from ethanol to give orange crystals. Yield $=75 \%$, m.p. $238^{\circ} \mathrm{C}-240^{\circ} \mathrm{C}$. Analytical data: Found: $\mathrm{C}=53.56, \mathrm{H}=2.59, \mathrm{~N}=22.46, \mathrm{~S}=12.75$ and $\mathrm{F}$ $=7.25 \%$. Calculated for $\mathrm{C}_{11} \mathrm{H}_{7} \mathrm{~N}_{4} \mathrm{SF}$ (246.5): $\mathrm{C}=53.65$, $\mathrm{H}=2.84, \mathrm{~N}=22.76, \mathrm{~S}=11.01$ and $\mathrm{F}=7.72 \%$. IR $(\mathrm{KBr}$ disk) $v \mathrm{~cm}^{-1}: 3358\left(\mathrm{NH}_{2}\right), 3120(\mathrm{NH}), 3010(\mathrm{C}-\mathrm{H}$ aromatic), $2226(\mathrm{C}=\mathrm{N}), 1630$ (deform. $\left.\mathrm{NH}_{2}\right), 1585(\mathrm{C}=\mathrm{N})$, 1230 (C-F), 1180 (C-S), 810 (substituted phenyl). UV (EtOH) $\lambda_{\max }(\mathrm{nm}) 370$.

${ }^{1} \mathrm{H}$ NMR (DMSO) $\delta: 8.7$ (s, NH), $3.4\left(\mathrm{~s}, \mathrm{NH}_{2}\right) .7 .4-$ $7.8,7.0-7.1$ (each $\mathrm{d}, 4 \mathrm{H}$ of aryl protons). ${ }^{13} \mathrm{C} \mathrm{NMR}$ (DMSO) $\delta$ : $180(\mathrm{C}=\mathrm{S}), 164(\mathrm{C}-\mathrm{CN}), 116(\mathrm{C}=\mathrm{N}), 92.7$ $(\mathrm{C}-\mathrm{CN}), 129.11,129.57,132.58,134.79$ (aromatic carbons). MS (m/z, \%): $248(\mathrm{M}+2,1.15), 206$ (10.11), $(95,100), 74$ (13.17).

2b: Crystallized from ethanol to give pale yellow crystals. Yield $=59 \%$, m.p. $175^{\circ} \mathrm{C}-177^{\circ} \mathrm{C}$. Analytical data: Found: $\mathrm{C}=46.81, \mathrm{H}=2.11, \mathrm{~N}=19.79, \mathrm{~S}=11.1$, $\mathrm{Cl}=12.51$ and $\mathrm{F}=7.25 \%$. Calculated for $\mathrm{C}_{11} \mathrm{H}_{6} \mathrm{~N}_{4} \mathrm{SCIF}$ (281): $\mathrm{C}=46.97, \mathrm{H}=2.13, \mathrm{~N}=19.92, \mathrm{~S}=11.38, \mathrm{CI}=$ $12.63, \mathrm{~F}=6.76 \%$.

2c: Crystallized from ethanol to give pale yellow crystals. Yield $=78 \%$, m.p. $300^{\circ} \mathrm{C}-302^{\circ} \mathrm{C}$. Analytical data: Found: $\mathrm{C}=44.43, \mathrm{H}=1.9, \mathrm{~N}=18.66, \mathrm{~S}=21.21$ and $\mathrm{F}=$ $12.15 \%$. Calculated for $\mathrm{C}_{11} \mathrm{H}_{6} \mathrm{~N}_{4} \mathrm{~S}_{2} \mathrm{~F}_{2}(296)$ : $\mathrm{C}=44.59, \mathrm{H}$ $=2.02, \mathrm{~N}=18.91, \mathrm{~S}=21.62$, and $\mathrm{F}=12.15 \%$.

\subsubsection{4-Fluoroaryl-2,5,7-trithioxo-l,6,8-trihydro- pyrimido [4,5-d] pyrimidines (3a-c)}

To a solution of $\mathbf{2 a - c}(0.01 \mathrm{~mol})$ in DMF $(30 \mathrm{~mL})$ or alcoholic $\mathrm{KOH}(5 \mathrm{gm} / 100 \mathrm{ml} \mathrm{EtOH}), \mathrm{CS}_{2}(20 \mathrm{ml})$ was added dropwise. The reaction mixture was refluxed on a water-bath for $12 \mathrm{hr}$. The solvent was evaporated and mass obtained was triturated with water then crystallized to give 3a-c.

3a: Crystallized from DMF to give orange crystals. Yield $=65 \%$, m.p. $250^{\circ} \mathrm{C}-252^{\circ} \mathrm{C}$. Analytical data: Found: $\mathrm{C}=44.52, \mathrm{H}=1.97, \mathrm{~N}=17.01, \mathrm{~S}=29.69$ and $\mathrm{F}$ $=5.66 \%$. Calculated for $\mathrm{C}_{12} \mathrm{H}_{7} \mathrm{~N}_{4} \mathrm{~S}_{3} \mathrm{~F}(322): \mathrm{C}=44.72, \mathrm{H}$ $=2.17, \mathrm{~N}=17.39, \mathrm{~S}=29.81 \mathrm{~F}=5.90 \% \mathrm{IR}(\mathrm{KBr}$ disk $) v$ $\mathrm{cm}^{-1}: 3305,3170,3095$ (3 NH) 1350 (NCS), 1298, 1222, $1180(\mathrm{C}-\mathrm{F}, \mathrm{C}=\mathrm{S}, \mathrm{C}-\mathrm{S})$. UV (EtOH) $\lambda_{\max }(\mathrm{nm}) 317(\log \epsilon$ $=3.01$ ). ${ }^{1} \mathrm{H}$ NMR (DMSO) $\delta$ : 13.2, 8.5 (each s, $3 \mathrm{H}$ of $\mathrm{NH}), 7.8-7.7,7.6-7.55$ (each d, $2 \mathrm{H}, 2 \mathrm{H}$ of aromatic protons). ${ }^{13} \mathrm{C}$ NMR (DMSO) $\delta: 180,172,170$ (3 C=S), 116 (C-F), 128.11, 128.0, 129.13, 129.0 (aromatic carbons), 145, $148(\mathrm{C}=\mathrm{C}$ of fused). $\mathrm{MS}(\mathrm{m} / \mathrm{e}, \%): 326(\mathrm{M}+4$, 1.15), 248 (5.11), 174 (23.11), 95 (100), 74 (3.14). 
3b: Crystallized from DMF to give orange crystals. Yield $=71 \%$, m.p. $300^{\circ} \mathrm{C}-303^{\circ} \mathrm{C}$. Analytical data: Found: $\mathrm{C}=39.96, \mathrm{H}=1.49, \mathrm{~N}=15.21, \mathrm{~S}=26,25, \mathrm{Cl}=$ 26.25 and $\mathrm{F}=$ 5.01. Calculated for $\mathrm{C}_{12} \mathrm{H}_{6} \mathrm{~N}_{4} \mathrm{~S}_{3} \mathrm{ClF}$ (365.5): $\mathrm{C}=40.39, \mathrm{H}=1.68, \mathrm{~N}=15.70, \mathrm{~S}=26,92, \mathrm{Cl}=9.95$ and $\mathrm{F}=5.39$.

3c: Crystallized from dilute DMF to give orange crystals. Yield $=60 \%$, m.p. $298^{\circ} \mathrm{C}-300^{\circ} \mathrm{C}$. Analytical data: Found: $\mathrm{C}=41.88, \mathrm{H}=1.6, \mathrm{~N}=16.47, \mathrm{~S}=28.23$ and $\mathrm{F}=$ 11.17. Calculated for $\mathrm{C}_{12} \mathrm{H}_{6} \mathrm{~N}_{4} \mathrm{~S}_{3} \mathrm{~F}_{2}$ (340): $\mathrm{C}=42.35, \mathrm{H}=$ $1.76, \mathrm{~N}=16.47, \mathrm{~S}=28.23$ and $\mathrm{F}=11.17 \%$.

\subsection{Formation of Schiff Base 4}

Equimolar mixture of $\mathbf{2 a}$ and 4-fluorobenzaldehyde in dry ethanol $(20 \mathrm{ml})$ was refluxed for $1 \mathrm{~h}$ and cooled. The solid obtained was crystallized to give 4 .

4: Crystallized from acetic acid to give yellow crystals. Yield $=85 \%$, m.p. $299^{\circ} \mathrm{C}-300^{\circ} \mathrm{C}$. Analytical data: Found: $\mathrm{C}=60.20, \mathrm{H}=2.77, \mathrm{~N}=15.55, \mathrm{~S}=8.55, \mathrm{~F}=$ $10.22 \%$ Calculated for $\mathrm{C}_{18} \mathrm{H}_{10} \mathrm{~N}_{4} \mathrm{SF}_{2}$ (352): $\mathrm{C}=61.36, \mathrm{H}$ $=2.84, \mathrm{~N}=15.90, \mathrm{~S}=9.09, \mathrm{~F}=10.79 \%$. (KBr disk) $v$ $\mathrm{cm}^{-1}: 3180(\mathrm{NH}), 3010$ (aromatic $\left.\mathrm{CH}\right), 2890$ (aliph. $\mathrm{CH}$ ), $2220(\mathrm{C} \equiv \mathrm{N}), 1590,1580(\mathrm{C}=\mathrm{N}), 1330(\mathrm{NCSN}) 1250$ (C-F), 1186 (C-S), 850, 820 ( $p$-substituted phenyl).

\subsubsection{4-(4'-Oxo-thiazolidin-3'-yl)-6-(4'-fluoro- phenyl)-2-thioxopyrimidine-5-carbonitrile (5)}

A mixture of compound $4(0.01 \mathrm{~mol})$, thioglycollic $(0.05$ $\mathrm{mol})$, in THF $(50 \mathrm{ml})$ was refluxed for $12 \mathrm{~h}$, cooled and then neutralized with acetic acid. The product was filtered and crystallized from $\mathrm{THF}$ to give $\mathbf{5}$ as yellow crystals. Yield $=68 \%$, m.p. $198^{\circ} \mathrm{C}-200^{\circ} \mathrm{C}$. Analytical data: Found: $\mathrm{C}=55.93, \mathrm{H}=2.59, \mathrm{~N}=13.01, \mathrm{~S}=14.38$ and $\mathrm{F}=8.80 \%$. Calculated for $\mathrm{C}_{20} \mathrm{H}_{12} \mathrm{~N}_{4} \mathrm{~S}_{2} \mathrm{~F}_{2} \mathrm{O}(426)$ : $\mathrm{C}=$ 56.33, $\mathrm{H}=2.81, \mathrm{~N}=13.14, \mathrm{~S}=15.02$ and $\mathrm{F}=8.92 \%$. IR $\left(\mathrm{KBr}\right.$ disk) $v \mathrm{~cm}^{-1}: 3373(\mathrm{OH}), 3329(\mathrm{NH}), 2229(\mathrm{C}=\mathrm{N})$, $1674(\mathrm{C}=\mathrm{O}), 1250$ (C-F), 1182 (C-S), 1490 (deform. $\left.\mathrm{CH}_{2}\right) .{ }^{1} \mathrm{H}$ NMR (DMSO) $\delta: 10.2(\mathrm{~s}, 1 \mathrm{H}, \mathrm{OH}$ of thiazole), 9.7 (s, $1 \mathrm{H}, \mathrm{NH}$ of pyrimidine), 7.7 - 7.4, 7.2 - 7.14 (each $\mathrm{m}, 8 \mathrm{H}$, aromatic protons), 4.25 (s, $1 \mathrm{H}, \mathrm{CH}=$ of thiazole).

\subsubsection{4-[4'-(4'-Fluorobenzylidene)-2-phenyl-5-oxo- imidazol-1-yl]-6-(4'-fluorophenyl)-2-thioxo- 1H-pyrimidine-5-carbonitrile (7)}

Equimolar amount of $\mathbf{2 a}$ and $\mathbf{6}$ in dry pyridine $(100 \mathrm{ml})$ was refluxed for $12 \mathrm{hr}$, cooled and then, poured onto ice-HCl. The resulted solid was filtered off and crystallized from ethanol to give 7 as brown crystals. Yield = $66 \%$, m.p. $258^{\circ} \mathrm{C}-260^{\circ} \mathrm{C}$. Analytical data: Found: $\mathrm{C}=$ $66.13, \mathrm{H}=2.99, \mathrm{~N}=14.01, \mathrm{~S}=6.06$ and $\mathrm{F}=7.32 \%$. Calculated for $\mathrm{C}_{27} \mathrm{H}_{15} \mathrm{~N}_{5} \mathrm{SF}_{2} \mathrm{O}$ (495): $\mathrm{C}=65.45, \mathrm{H}=3.03, \mathrm{~N}$ $=14.14, \mathrm{~S}=6.46, \mathrm{~F}=7.67 \%$. IR (KBr disk) $v \mathrm{~cm}^{-1} 3329$ (NH), 3020 (aromatic CH), 2910 (aliphatic CH), 2225
$(\mathrm{C} \equiv \mathrm{N}), 1650(\mathrm{C}=\mathrm{O}), 1610(\mathrm{C}=\mathrm{CH}), 1238,677(\mathrm{C}-\mathrm{F})$, 1180 (C-S). UV (EtOH) $\lambda_{\max }(\mathrm{nm}) 360(\log \epsilon=2.5) .{ }^{1} \mathrm{H}$ NMR (DMSO) $\delta$ : 13.2, $8.5(\mathrm{~s}, 1 \mathrm{H}, \mathrm{NH}), 8.6(\mathrm{~d}, 1 \mathrm{H}$, exo $\mathrm{CH}=$ ), $7.9-7.7,7.6-7.45,7.15-6.95$ (each $\mathrm{m}, 9 \mathrm{H}$ of aromatic protons).

\subsubsection{8-(Phthalimido-1'-yl)-6-(4'-fluorophenyl)-2- thioxo-lH-pyrimidine-5-carbonitriale (9)}

A mixture of $\mathbf{2 a}(0.01 \mathrm{~mol})$ and pyridine-2,3-dicarboxylic anhydride $(8)(0.01 \mathrm{~mol})$ in dry pyridine $(50 \mathrm{ml})$ was refluxed for $10 \mathrm{~h}$., cooled and then poured onto ice-HCl. The produced solid was filtered and crystallized from THF to give 9 as deep brown crystals. Yield 55\%, m.p. $299^{\circ} \mathrm{C}-300^{\circ} \mathrm{C}$. Analytical data: Found: $\mathrm{C}=57.10, \mathrm{H}=$ $1.98, \mathrm{~N}=18.41, \mathrm{~S}=7.84$ and $\mathrm{F}=4.90 \%$. Calculated for $\mathrm{C}_{18} \mathrm{H}_{8} \mathrm{~N}_{5} \mathrm{SFO}_{2}$ (377): $\mathrm{C}=57.29, \mathrm{H}=2.12, \mathrm{~N}=18.56, \mathrm{~S}=$ $8.48, \mathrm{~F}=4.90 \%$. IR (KBr disk) $v \mathrm{~cm}^{-1}: 3334(\mathrm{NH}), 2216$ $(\mathrm{C} \equiv \mathrm{N}), 1700$ - $1689(2 \mathrm{C}=\mathrm{O}), 1600,15802(\mathrm{C}=\mathrm{N}), 1230$ (C-F), 1189 (C-S), 900, 820 (substituted pyrimidine and aryl). UV (EtOH) $\lambda_{\max }(\mathrm{nm}) 302(\log \epsilon=1.5) .{ }^{1} \mathrm{H}$ NMR (DMSO) $\delta: 10.1(\mathrm{~s}, 1 \mathrm{H}, \mathrm{NH}), 7.80-7.77(\mathrm{~m}, 4 \mathrm{H}$ of pyridine), $7.65-7.51$ (m, $4 \mathrm{H}$ of aromatic protons).

\subsubsection{8-(2'-Chloro-6"-fluorophenyl)-2,5,7- tri(carboxymethylthia)-3H,4H-pyrimido[4,5-d] pyrimidine (10)}

A mixture of 3a $(0.01 \mathrm{~mol})$ and chloroacetic acid $(0.03$ $\mathrm{mol})$ in DMF $(50 \mathrm{ml})$ was refluxed for $2 \mathrm{~h}$, and then poured onto ice. The solid thus obtained was filtered off and crystallized from THF to give $\mathbf{1 0}$ as yellow crystals. Yield $=80 \%$, m.p. $130^{\circ} \mathrm{C}-132^{\circ} \mathrm{C}$. Analytical data: Found: $\mathrm{C}=43.41, \mathrm{H}=2.33, \mathrm{~N}=11.31, \mathrm{~S}=19.39$ and $\mathrm{F}$ $=3.55 \%$. Calculated for $\mathrm{C}_{18} \mathrm{H}_{12} \mathrm{~N}_{4} \mathrm{~S}_{3} \mathrm{FO}_{6}(495): \mathrm{C}=43.63$, $\mathrm{H}=2.42, \mathrm{~N}=11.11, \mathrm{~S}=18.39, \mathrm{~F}=3.83 \%$. IR (KBr disk) $v \mathrm{~cm}^{-1}: 3400(\mathrm{OH}), 3050$ (aromatic $\left.\mathrm{CH}\right), 2890$ (aliphatic $\left.\mathrm{CH}_{2}\right), 1700(\mathrm{C}=\mathrm{O}), 1590,1580(2 \mathrm{C}=\mathrm{N}), 1480$ (deform. $\left.\mathrm{CH}_{2}\right) 1230(\mathrm{C}-\mathrm{F}), 1180$ (C-S). ${ }^{1} \mathrm{H}$ NMR (DMSO) $\delta: 9.0-$ $7.2(\mathrm{~m}, 3 \mathrm{H}, 3 \mathrm{OH}), 8.0-7.77$ (m, $4 \mathrm{H}$ of aromatic protons), $3.6-3.3\left(\mathrm{~m}, 6 \mathrm{H}, 3 \mathrm{CH}_{2}\right)$.

\subsubsection{8-(2'-Chloro-6'-fluorophenyl)-2,5,7-tri (4'-fluorophenylamino)-pyrimido[4,5-d] pyrimidine (11)}

A mixture of 3a $(0.01 \mathrm{~mol})$ and 4-fluoroaniline $(0.03 \mathrm{~mol})$ in abs. EtOH $(100 \mathrm{ml})$ was refluxed for $12 \mathrm{hr}$ and cooled. The resulted solid was filtered and crystallized from THF to give 11 as yellow crystals. Yield $=78 \%$, m.p. $115^{\circ} \mathrm{C}$ $117^{\circ} \mathrm{C}$. Analytical data: Found: $\mathrm{C}=64.69, \mathrm{H}=3.33, \mathrm{~N}=$ 17.55, and $\mathrm{F}=13.45 \%$. Calculated for $\mathrm{C}_{30} \mathrm{H}_{19} \mathrm{~N}_{7} \mathrm{~F}_{4}$ (553): $\mathrm{C}=65.09, \mathrm{H}=3.43, \mathrm{~N}=17.72$ and $\mathrm{F}=13.74 \%$. IR $(\mathrm{KBr}$ disk) $v \mathrm{~cm}^{-1}: 3197(\mathrm{NH}), 1575(\mathrm{C}=\mathrm{N}), 1235,676(\mathrm{C}-\mathrm{F})$, 1219 (C-S) and 776 (substituted phenyl). UV (EtOH) $\lambda_{\max }(\mathrm{nm}) 271(\log \epsilon:=1.2) .{ }^{1} \mathrm{H}$ NMR $(\mathrm{DMSO}) \delta: 10.1(\mathrm{~s}$, 
$3 \mathrm{NH}$ of pyrimidine), $7.9-7.2$ (m, $16 \mathrm{H}$ of aromatic protons).

\subsubsection{8-(2",6-Difluorophenyl)-2,5,7-tri (4'-sulphonamoyphenyllamino)-pyrimido [4,5-d]pyrimidine (12)}

A mixture of $3 \mathbf{c}(0.01 \mathrm{~mol})$ and sulfadiazine $(0.03 \mathrm{~mol})$ in DMF-EtOH (1:1, $100 \mathrm{ml})$ was refluxed for $8 \mathrm{hr}$, cooled and then poured onto ice. The produced solid was filtered and crystallized from THF to give $\mathbf{1 2}$ as deep brown crystals. Yield $=55 \%$, m.p. $230^{\circ} \mathrm{C}-232^{\circ} \mathrm{C}$. Analytical data: Found: $\mathrm{C}=50.81, \mathrm{H}=2.95, \mathrm{~N}=22.67, \mathrm{~S}=9.51$ and $\mathrm{F}=3.48 \%$. Calculated for $\mathrm{C}_{42} \mathrm{H}_{30} \mathrm{~N}_{16} \mathrm{~S}_{3} \mathrm{~F}_{2} \mathrm{O}_{6}$ (988): $\mathrm{C}$ $=51.01, \mathrm{H}=3.03, \mathrm{~N}=22.67, \mathrm{~S}=9.71, \mathrm{~F}=3.84 \%$. IR (KBr disk) $v \mathrm{~cm}^{-1}: 3100-3080(\mathrm{NH}), 3020$ (aromatic $\mathrm{CH}), 1595,1580(\mathrm{C}=\mathrm{N}), 1350$ (NCS), 1230 (C-F), 900, $870,850,820$ (substituted phenyl).

\subsubsection{8-(4'-Fluorophenyl)-2,5,7-tri-(hydrazine)- pyrimido[4,5-d]pyrimidine (13)}

A mixture of compound 3a $(0.01 \mathrm{~mol})$ and hydrazine hydrate $(0.03 \mathrm{~mol})$ in abs. EtOH $(100 \mathrm{ml})$ was refluxed for $12 \mathrm{hr}$, cooled and then concentrated. The obtained solid was crystallized from ethanol to give $\mathbf{1 3}$ as yellow crystals. Yield $=78 \%$, m.p. $170^{\circ} \mathrm{C}-172^{\circ} \mathrm{C}$. Analytical data: Found: $\mathrm{C}=45.14, \mathrm{H}=3.95, \mathrm{~N}=44.30$ and $\mathrm{F}=$ $5.88 \%$. Calculated for $\mathrm{C}_{12} \mathrm{H}_{13} \mathrm{~N}_{10} \mathrm{FO}(316)$ : $\mathrm{C}=45.56, \mathrm{H}$ $=4.11, \mathrm{~N}=44.01$ and $\mathrm{F}=6.01 \%$. IR (KBr disk) $v \mathrm{~cm}^{-1}$ $3300\left(\mathrm{NH}_{2}\right), 3095(\mathrm{NH}), 3020$ (aromatic $\mathrm{C}-\mathrm{H}$ ), 1620 (deform. $\left.\mathrm{NH}_{2}\right), 1580,1540(\mathrm{C}=\mathrm{N}), 1250(\mathrm{C}-\mathrm{F})$.

\subsubsection{8-(4'-Fluorophenyl)-2,5,7-tri( $3^{\prime}, 5^{\prime}$ - diaminopyrazol-l'-yl)pyrimido[4,5-d] pyrimidine (14)}

A mixture of $13(0.01 \mathrm{~mol})$ and malononitrile $(0.03 \mathrm{~mol})$ in ethanol $(50 \mathrm{ml})$ with a few drops of piperidine was refluxed for $4 \mathrm{hr}$ and cooled. The resultant solid was crystallized from dioxin as yellow crystals to give $\mathbf{1 4}$. Yield $=66 \%$, m.p. $235^{\circ} \mathrm{C}-237^{\circ} \mathrm{C}$. Analytical data: Found: $\mathrm{C}=48.48, \mathrm{H}=3.61, \mathrm{~N}=43.17$ and $\mathrm{F}=3.19 \%$. Calculated for $\mathrm{C}_{21} \mathrm{H}_{19} \mathrm{~N}_{16} \mathrm{~F}(514)$ : $\mathrm{C}=49.02, \mathrm{H}=3.69, \mathrm{~N}$ $=43.57$ and $\mathrm{F}=3.69 \%$. IR ( $\mathrm{KBr}$ disk) $v \mathrm{~cm}^{-1}: 3240$ $\left(\mathrm{NH}_{2}\right), 1664$ (deform. $\left.\mathrm{NH}_{2}\right), 1609,1574(\mathrm{C}=\mathrm{N}), 1230$ (C-F). UV (EtOH) $\lambda_{\max }(\mathrm{nm}) 350(\log \epsilon=2.5) .{ }^{1} \mathrm{H}$ NMR (DMSO) $\delta: 8.18$ - 8.00 (each s, $3 \mathrm{H}$ of $\mathrm{C}_{4}$-pyrazole), 7.8 $7.2(\mathrm{~m}, 4 \mathrm{H}$, aromatic protons), $3.6-3.3(\mathrm{~m}, 12 \mathrm{H}$ of 6 $\mathrm{NH}_{2}$ of pyrazole). MS (m/e, \% $=223(\mathrm{M}-291,13.11)$, 223 (5.19), 128 (17.33), 97 (25.18) and 95 (100).

\section{Acknowledgements}

We would like to thanks the Deanship of Scientific Research, King Abdul Aziz University, Jeddah, for supporting this Research. Thanks extend to Prof. Z. ElBazza and co-workers, Pharmamicrobiological Lab, Na- tional Centre, Cairo, Egypt.

\section{REFERENCES}

[1] M. S. T. Makki, D. A. Bakhotmah and R. M. AbdelRahman, "Highly Efficient of Novel Fluorine Bearing Quinoline-4-Carboxylic Acid and the Related Compounds as Amylolytic Agents against Some Aspergillus Fungi," International Journal of Organic Chemistry, Vol. 2, No. 1, 2012, pp. 49-53. doi:/10.4236/ijoc.2012.21009

[2] R. M. Abdel-Rahman, M. S. T. Makki and W. A. Bawazir, "Synthesis of Some More Fluorine Heterocyclic Nitrogen Systems Derived from Sulfa-Drugs as Photochemical Probe Agents for Inhibition of Vitiligo Disease-Part I," E-Journal of Chemistry, Vol. 8, No. 1, 2011, pp. 404-414.

[3] R. M. Abdel-Rahman, M. S. T. Makki and W. A. Bawazir, "Synthesis of Some More Fluorine Heterocyclic Nitrogen Systems Derived from Sulfa-Drugs as Photochemical Probe Agents for inhibition of Vitiligo Disease-Part II," E-Journal of Chemistry, Vol. 7, No. S1, 2010, pp. S93S101.

[4] D. J. Wang, L. Fan, C. Y. Zheng and Z. D. Fang, "Synthesis and Antimicrobial Activity of Some New Fluorinated 1H-Pyrazoles," Journal of Fluorine Chemistry, Vol. 131, No. 5, 2010, pp. 584-586.

doi:/10.1016/j.jfluchem.2010.01.005

[5] R. Fillen and R. Saha, "Fluorine in Medicinal Chemistry: A Century of Progress and a 60-Year Retrospective of Selected Highlights Future," Journal of Medicinal Chemistry, Vol. 1, No. 5, 2009, pp. 777-791.

[6] G. Sandford, "Elemental Fluorine in Organic Chemistry (1997-2006)," Journal of Fluorine Chemistry, Vol. 128, No. 2, 2007, pp. 90-104.

doi:/10.1016/j.jfluchem.2006.10.019

[7] C. Isanbor and D. OHagan, "Fluorine in Medicinal Chemistry: A Review of Anticancer Agents," Journal of Fluorine Chemistry, Vol. 127, No. 3, 2006, pp. 303-319. doi:/10.1016/j.jfluchem.2006.01.011

[8] B. E. Smart, "Fluorine Substituent Effect (on Bioactivity) A-Review," Journal of Fluorine Chemistry, Vol. 109, No. 1, 2001, pp. 3-11. doi:/10.1016/S0022-1139(01)00375-X

[9] S. Liu, X. Qian, G. Song, J. Chem and W. Chen, "Fluorine Containing Heterocyclic Compounds: Synthesis of 6-Substituted-2-substitutedaryl-1,2,4-triazolo[5,1-b][1,3,5]-thiadiazin-7-one Derivatives," Journal of Fluorine Chemistry, Vol. 105, No. 1, 2000, pp. 111-115. doi:/10.1016/S0022-1139(00)00287-6

[10] R. M. Abdel-Rahman, "Synthesis and Chemistry of Fluorine Containing Bioactive 1,2,4-Triazines-An Overview," $\mathrm{Ph}$ armazie, Vol. 54, No. 11, 1999, pp. 791-803.

[11] A. T. Ramadan, R. M. Abdel-Rahman and M. Seada, "Studies on Complexes of $\mathrm{Cu}(\mathrm{II}), \mathrm{Ni}(\mathrm{II}), \mathrm{Co}(\mathrm{II})$ and $\mathrm{Ln}(\mathrm{II})$ with 3-( $\alpha$-Benzoyl)benzylidene Hydrazino-5,6-diphen-yl1,2,4-triazine," Asian Journal of Chemistry, Vol. 4, 1992, pp. 569-575.

[12] A. T. Ramadan, R. M. Abdel-Rahman, M. A. El-Behairy, A. I. Ismail and M. M. Mohamud, "Thermodynamics of Complexation of Transition and Lanthanide Ions by 3- $(\alpha-\mathrm{Car}-$ boxy-methylamino)benzylidene Hydrazino-5,6-diphenyl-1,2, 
4-triazine," Thermochimica Acta, 1993, pp. 222-291.

[13] F. M. Foss, Best Practice \& Research Clinical Haematology, Vol. 17, 2004, pp. 573-584.

[14] E. K. Rowinsky, "Signal Events: Cell Signal Transduction and Its Inhibition in Cancer," Oncologist, Vol. 8, No. Supplement 3, 2003, pp. 5-17. doi:/10.1634/theoncologist.8-suppl 3-5

[15] G. Cockerill and K. E. Lackey, Current Topics in Medicinal Chemistry, Vol. 2, 2002, pp. 1001-1010.

[16] V. Aparna, G. Rambabu, S. K. Panigrahi, J. A. R. P. Sharma and G. R. Desiraju, Journal of Chemical Information and Modeling, Vol. 45, 2005, pp. 725-738.

[17] S. Emanuel, R. H. Gruninger, A. F. Pasquera, P. J. Connoly, J. A. Seamon, S. Hazel, R. Tominovich, B. Hollister, C. Napier, M. R. D'Andrea, M. Reuman, G. Bignan, R. Tuman, D. Johnson, D. Moffati, M. Batchelor, A. Foley, J. O. Connel, R. Allen, M. Perry, L. Jolliffe and S. A. Middleton, "A Vascular Endothelial Growth Factor Receptor-2 Kinase Inhibitor Potentiates the Activity of the Conventional Chemotherapeutic Agents Paclitaxel and Doxorubicin in Tumor Xenograft Models," Molecular Pharmacology, Vol. 66, No. 3, 2004, pp. 635-647. doi:/10.1124/mol.104.000638

[18] R. M. Fikry, "Synthesis of Some Pyrimidine and Condensed Derivatives," Indian Journal of Heterocyclic Chemistry, Vol. 4, 1995, pp. 265-268.

[19] R. M. Abdel-Rahman, "Chemoselective Heterocyclization and Pharmacological Activities of New Heterocycles-A Review Part V-Synthesis of Biocidal 4-Thiazolidinones Derivatives," Bollettino Chimico Farmaceutico, Vol. 140, No. 6, 2001, pp. 401-410.

[20] R. M. Abdel-Rahman and M. S. Abdel-Malik, "Synthesis of Some New 3,6-Diketoaryl-1,2,4-triazin-5-ones and Their Effects on Amylolytic Activity of Some Fungi,"
Pakistan Journal of Science and Industrial Research, Vol. 33, 1990, pp. 142-147.

[21] R. M. Abdel-Rahman, "Synthesis and Antihuman Immune Virus Activity of Some New Fluorine Containing Substituted 3-Thioxo-1,2,4-triazin-5-ones," Farmaco, Vol. 46, No. 2, 1991, pp. 379-385.

[22] R. M. Abdel-Rahman, "Synthesis of Some New Fluorine Bearing Trisubstituted 3-Thioxo-1,2,4-triazin-5-one as Potential Cancer Agents, Farmaco, 1991, Vol. 47, No.3, pp. 319-324.

[23] E. De Clercq, "New Developments in Anti HIV Chemotherapy," Biochimica et Biophysica Acta, Vol. 1587, No. 2-3, 2002, pp. 258-275. doi:/10.1016/S0925-4439(02)00089-3

[24] W. R. Abdel-Monem and R. M. Abdel-Rahman, "Synthesis of 3-Heteroaryl-6,7-diphenyl-1,2,4-triazo-lo[4,3-b] $[1,2,4]$ tria-zines and Their Biological Activities," International Journal of Chemistry, Vol. 16, No. 1, 2006, pp. $1-14$.

[25] R. M. Abdel-Rahman and W. R. Abdel-Monem, "Chemical Reactivity of 3-Hydrazino-5,6-diphenyl-1,2,4-triazine towards Acceptors Activated Carbonitriles," Indian Journal of Chemistry, Vol. 46B, No. 5, 2007, pp. 838-846.

[26] T. E. Ali, "Synthesis of Some Novel Pyrazolo[3,4b]pyridine and Pyrazolo[3,4-d]pyrimidine Derivatives Bearing 5,6-Diphenyl-1,2,4-triazine Moiety as Potential Antimicrobial Agents," European Journal of Medicinal Chemistry, Vol. 44, No. 11, 2009, pp. 4385-4392.

[27] A. L. Barry and C. Thornsberry, "In Susceptibility Testing Diffusion Tests Procedure," American Society for Microbiology, Washington, 1981.

[28] M. J. Weinstein and G. H. Nagman, "In Antibiotics," Elsevier Scientific Publishing Company, Amesterdam, 1987. 